\title{
ESTIMATION OF AN EFFECTIVE YOUNG'S MODULUS OF ELASTICITY IN THE LOCALITY OF THE GABČÍKOVO HYDROLOGY POWER PLANT BY GEOMETRIC LEVELING
}

\author{
Marcel MOJZEŠ ${ }^{1 *}$, Pavol KOLLÁR ${ }^{2}$, Michal MIKOLAJ ${ }^{1}$
}

\begin{abstract}
The Gabčikovo hydroelectric power plant is located in a complicated geological environment (gravel sub-soil and a high groundwater level). Excavation work started after the withdrawal of water in the autumn of 1984 and lasted until the autumn of 1986. A basic geodetic control network with a special monument was founded before the excavation work began. This network served for the setting-out of the hydroelectric power plant as well as for the control of the excavation work. The repeated geodetic control measurements have been evaluated and presented at many seminars and conferences. Monitoring the horizontal and vertical stability of the geodetic control network during the general site excavation showed significant horizontal and vertical deformations. The paper is focused on an estimation of an effective Young's modulus of elasticity in the area studied.
\end{abstract}

Address

1 Department of Theoretical Geodesy, Faculty of Civil Engineering, Slovak University of Technology in Bratislava, Radlinského 11, 81005 Bratislava, Slovakia

2 Department of Structural Mechanics, Faculty of Civil Engineering, Slovak University of Technology in Bratislava, Radlinského 11, 81005 Bratislava, Slovakia

*Corresponding author: marcel.mojzes@stuba.sk

\section{Key words}

- Elasticity deformation,

- Boussinesq's homogeneous elastic half-space,

- Young's modulus,

- Green's function.

\section{INTRODUCTION}

Information about the Earth's surface deformations due to the transfer of materials during construction in the vicinity of large structures is very important for the establishment of a geodetic network. This problem manifests itself in the form of certain patterns that are important to know for the surveyors who prepare the establishment of the network for the setting-out and monitoring of a structure. The repeated geodetic measurements (permanent or non-permanent - repeated after some time) have a high degree of accuracy and can serve for the monitoring of the Earth's surface deformations. Mass movements during the construction produce horizontal and vertical changes in the Earth's surface. Conventional surveying techniques, such as precise leveling and angle and distance measurements served in the past for monitoring vertical and horizontal deformations. An analysis of the geodetic measurements showed that the Earth's surface deformations are caused by seasonal, regional and local phenomena such as the surface water load, snow load, groundwater load or the load of the atmosphere pressure. A current analysis of the permanent Global Navigation Satellite Systems (GNSS) measurements shows a season- al variation in the measured signals in the form of a winter snow load or unloading due to the melting of snow in the spring and summer.

The process of the deformations can be modelled using a purely elastic model based on Green's function (Pinel et al., 2007). This is then compared to the measured values, which can be used to study the structural properties of the sub-soil. The modelling of the ground deformation process and its measurement enables the detection of patterns that are very important for practical activities. The next section will only focus on the modelling of the Earth's surface deformations in a vertical direction. Leveling measurements with a high degree of precision in the locality of the Gabčíkovo hydroelectric power plant served for this purpose.

\section{MEASURING VERTICAL CHANGES IN THE BASIC SETTING-OUT NETWORK AT GABČÍKOVO}

The basic control network of the Gabčíkovo hydroelectric power plant consists of 12 specially stabilized points. Steel tubes with a di- 
Tab. 1 Mean kilometer error of the levelling.

\begin{tabular}{|c|c|}
\hline Date & Mean kilometer error of the levelling $(\mathrm{mm})$ \\
\hline Autumn 1984 & 0.39 \\
\hline Autumn 1986 & 0.30 \\
\hline
\end{tabular}

ameter of $30 \mathrm{~cm}$ and iron rods were filled with concrete up to a depth of five meters. These pillars were up to five meters high above the ground (Janek, 1984). The height network (leveling network) for the precise leveling consisted of a main leveling line, with the first point at the Gabčíkovo church (point 31a of the Slovak Levelling Network), which is identical to the GK point and the end point at the Gabčíkovo port (point 90.3 of the Slovak Levelling Network). This main leveling line with ten points between the endpoints was six kilometers long. The main levelling line was measured first. The side levelling line consisted of 12 fundamental points and three detailed survey points of the setting-out network. A standard procedure was chosen for this measurement, i.e., back and forth measurements. The side leveling line was measured after the main leveling line. The measurements were performed with the Zeiss Ni 002 rectified leveling instrument and two invar leveling rods (Mitáš and Klajban, 1987). The first leveling measurements were performed in the autumn of 1984. The excavation work for the hydroelectric power plant began at the same time. The last leveling measurement used for the analysis was carried out in the autumn of 1986, when the excavation work was almost completed.

Tab. 1 presents the mean basic kilometer errors for the first and second measurements. These values document the high precision of the leveling measurements. Tab. 2 presents the height differences between the first and second measurements in the autumn of 1984 and the autumn of 1986.

\section{MODELLING OF THE EARTH'S SURFACE DEFORMATIONS}

The effect of the cylinder load on the Earth's surface was analyzed in detail in (Kollár et al., 2009). The numerical calculations require a realistically estimated Young's modulus of the sub-soil. An error in the Young's modulus estimated would cause unrealistic results. The effect of the unloading of the Earth's surface is a process that occurs in the vicinity of buildings due to the mass displacements during excavation works. These changes result in deformations in both the horizontal as well as in the vertical directions. The deformations impact local geodetic networks implemented for the purpose of monitoring structures.
Tab. 2 Height differences between the first and second measurements.

\begin{tabular}{|c|c|}
\hline Measured point & Difference (Autumn 1984-Autumn 1986) (mm) \\
\hline GK & 0.0 \\
\hline NB1 & 0.0 \\
\hline NB2 & 0.0 \\
\hline NB4 & 7.5 \\
\hline PB7 & 21.0 \\
\hline PB9 & 20.0 \\
\hline PB11 & 8.0 \\
\hline DB11 & 11.0 \\
\hline PB10 & 7.0 \\
\hline PB8 & 27.0 \\
\hline PB6 & 31.0 \\
\hline PB5 & 12.0 \\
\hline PB3 & 14.0 \\
\hline DB4 & 15.0 \\
\hline DB1 & 25.0 \\
\hline PB4 & 12.0 \\
\hline DB5 & 18.0 \\
\hline PB1 & 5.0 \\
\hline HVB64 & -2.0 \\
\hline NB6 & -4.5 \\
\hline PR & -4.0 \\
\hline 90.3 & -1.0 \\
\hline & \\
\hline & \\
\hline PB 30 \\
\hline PB
\end{tabular}

The theoretical basis for modelling the Earth's surface deformations in the case of homogeneous elastic half-spaces was founded by Boussinesq (1885). It deals with the solution of linear differential equations, which have been developed by many researchers in analytical or numerical forms using the finite element method. This is performed for different forms of deformation elements. Green's functions are a mathematical tool for solving linear differential equations. These functions are obtained in an analytical form for a specific problem. Equation 1 represents the elastic response to a rectangular load. It is expressed as a product of Green's function and the load (Kollár, 2010, unpublished), where $E$ is the Young's modulus; $\mu$ is the Poisson number; $x, y$ are the Cartesian coordinates of the calculation points; and $a, b$ are the Cartesian coordinates of the object causing the deformation. The symbol $p$ in Equation 1 represents the pressure on the area bounded by the coordinates $a, b$ (Fig. 1).

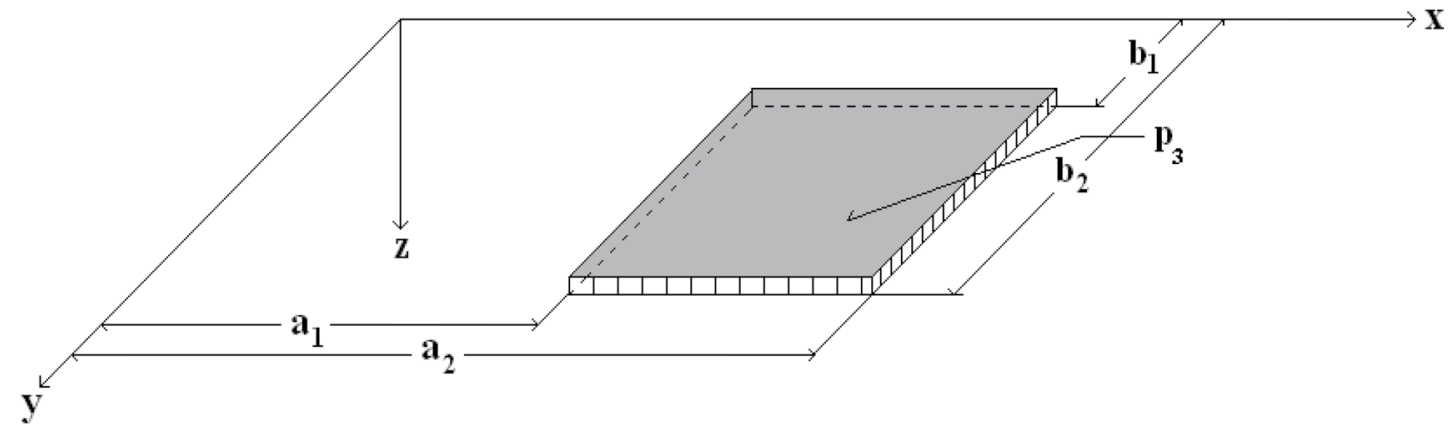

Fig. 1 The horizontal Cartesian coordinates of the calculation points. 


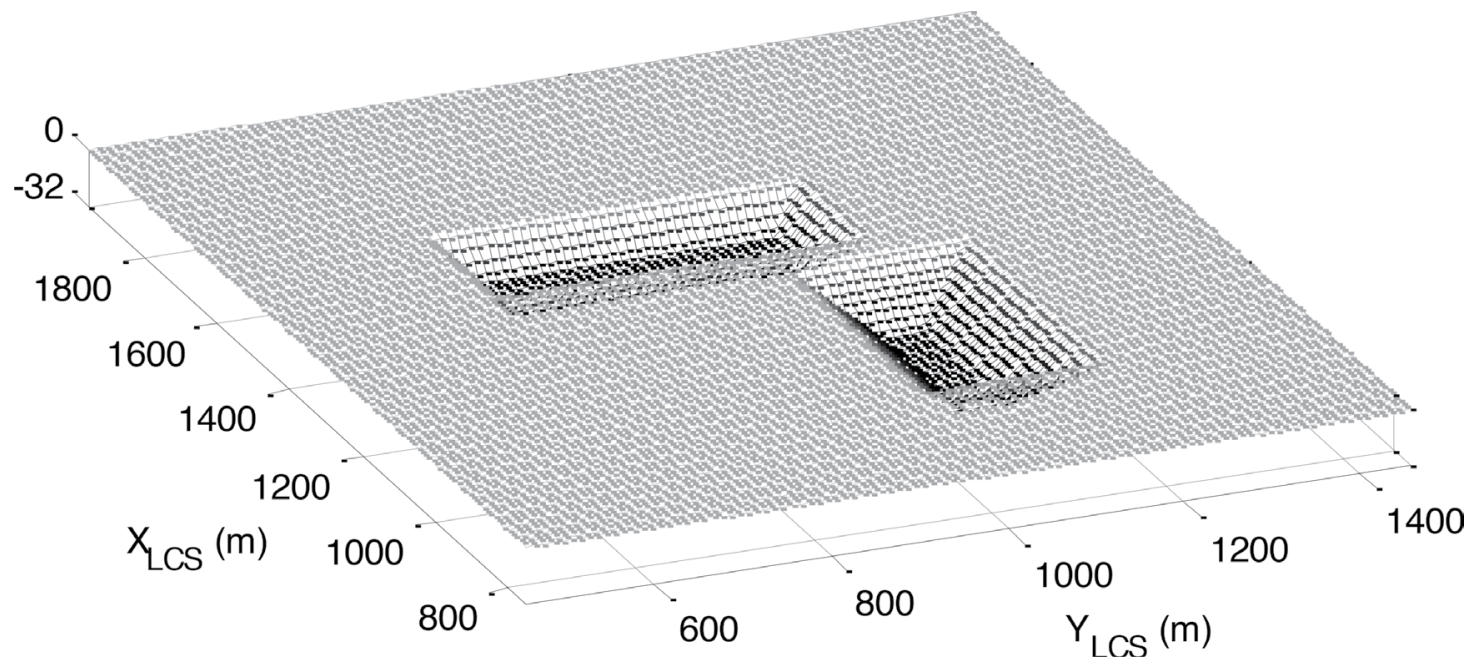

Fig. 2 Excavation pits for the hydroelectric power plant and navigation locks in the local coordinate system (LCS).

$$
v_{z}(x, y)=\frac{\left(1-\mu^{2}\right) p}{\pi E}\left[\begin{array}{c}
\left(y-b_{1}\right) \ln \frac{x-a_{1}+\sqrt{\left(x-a_{1}\right)^{2}+\left(y-b_{1}\right)^{2}}}{x-a_{2}+\sqrt{\left(x-a_{2}\right)^{2}+\left(y-b_{1}\right)^{2}}}+ \\
\left(y-b_{2}\right) \ln \frac{x-a_{2}+\sqrt{\left(x-a_{2}\right)^{2}+\left(y-b_{2}\right)^{2}}}{x-a_{1}+\sqrt{\left(x-a_{1}\right)^{2}+\left(y-b_{2}\right)^{2}}}+ \\
\left(x-a_{1}\right) \ln \frac{y-b_{1}+\sqrt{\left(x-a_{1}\right)^{2}+\left(y-b_{1}\right)^{2}}}{y-b_{2}+\sqrt{\left(x-a_{1}\right)^{2}+\left(y-b_{2}\right)^{2}}}+ \\
\left(x-a_{2}\right) \ln \frac{y-b_{2}+\sqrt{\left(x-a_{2}\right)^{2}+\left(y-b_{2}\right)^{2}}}{y-b_{1}+\sqrt{\left(x-a_{2}\right)^{2}+\left(y-b_{1}\right)^{2}}}
\end{array}\right]
$$

The numerical solution of the Boussinesq problem by the finite element method is given, for instance, in Zienkiewicz (1972).

\section{EFFECTIVE ESTIMATION OF THE YOUNG'S MODULUS OF ELASTICITY}

The Young's modulus of elasticity for sub-soil can be determined by laboratory measurements or by measuring the propagation of seismic waves in the soil examined. A local static Young's modulus (Pinel et al., 2007) can also be estimated from geodetic measurements using the least squares method, i.e., searching for the minimum differences between the vertical measured and modelled changes according to Equation 1. The effective Young's modulus of elasticity is the one in which the standard deviation between the above-mentioned differences reaches the minimum (Grapenthin et al., 2006). This approach assumes a constant Young's modulus in the whole area studied.

The effective estimation of the Young's modulus was performed by calculating the vertical deformations at different points with the height changes measured. This was done for different elastic modulus. An effective estimation of Young's modulus corresponds to the minimum value of the standard deviation obtained by Equation (2), where $v_{i}$ is the difference between the measured and modelled changes in height. The symbol $\bar{v}$ represents the average of these differences. The calculation was performed for 19 points (the symbol $n$ in Equation (2)). The points where a subsidence was observed (points at the port) were not included in these calculations. The reason for that is the possible impact of changes in the water level of the Danube River.

$$
\sigma_{E}=\sqrt{\frac{1}{n-1} \sum_{i=1}^{n}\left(v_{i}-\bar{v}\right)^{2}}
$$

The projected dimensions of the structure's pits were used for the calculations, i.e., $380 \mathrm{~m} \times 210 \mathrm{~m}$ for the upper part of the hydroelectric power plant and $220 \mathrm{~m} \times 50 \mathrm{~m}$ for the bottom with a depth of $32 \mathrm{~m}$. The following dimensions of the navigation locks were used: $180 \mathrm{~m} \times 420 \mathrm{~m}$ for the upper part, $80 \mathrm{~m} \mathrm{x} 320 \mathrm{~m}$ for the bottom, and a depth of $22 \mathrm{~m}$ (see Fig. 1). The constant density of $1800 \mathrm{~kg} / \mathrm{m}^{3} \mathrm{de}-$ termined from laboratory measurements of the sub-soil (Slávik, 2011) was used for the calculations of the pressure $(p)$ in Equation 1.

Tab. 3 and Fig. 3 presents the changing standard deviations of the difference between the modelled and measured deformations with respect to the Young's modulus. The minimum of the function is located at the point that corresponds to the effective Young's modulus of elasticity and has a value of $2914 \mathrm{MPa}$.

Tab. 3 Standard deviation computation for selected Young's modulus of elasticity.

\begin{tabular}{|c|c|c|c|c|c|c|}
\hline $\begin{array}{c}\text { Yuang's Modulus } \\
(\mathrm{MPa})\end{array}$ & 2000 & 2500 & 3000 & 3500 & 4000 & 4500 \\
\hline $\begin{array}{c}\text { Standard } \\
\text { Deviation (mm) }\end{array}$ & 6.069 & 5.031 & 4.869 & 5.036 & 5.317 & $5 . ; 611$ \\
\hline
\end{tabular}

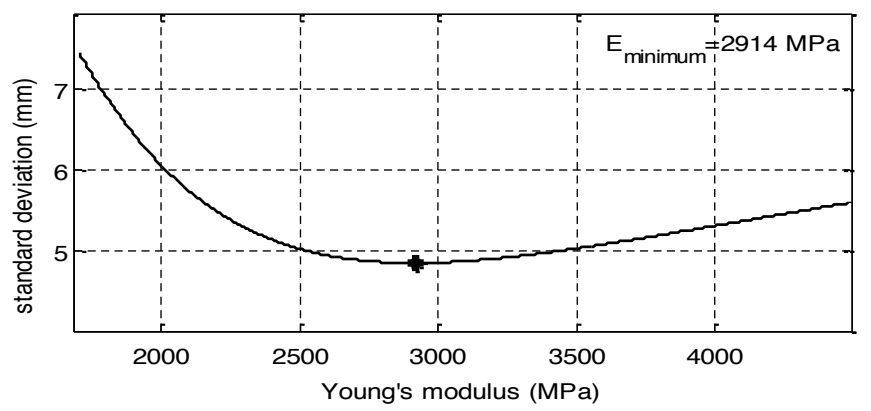

Fig. 3 Effective estimation of the Young's modulus of elasticity. 


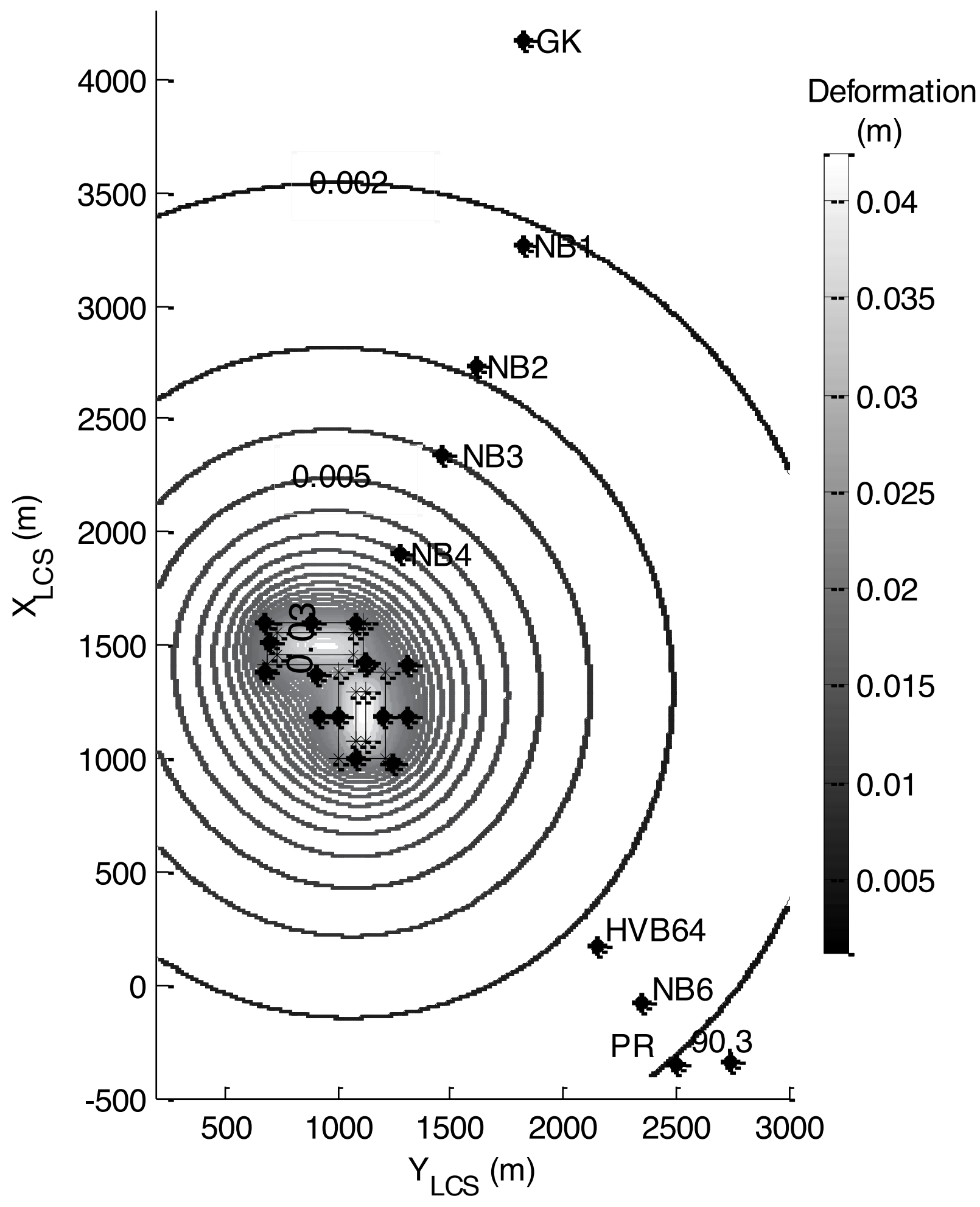

Fig. 4 Overall situations - the points of the levelling line and deformations caused by the structure of the pits. 


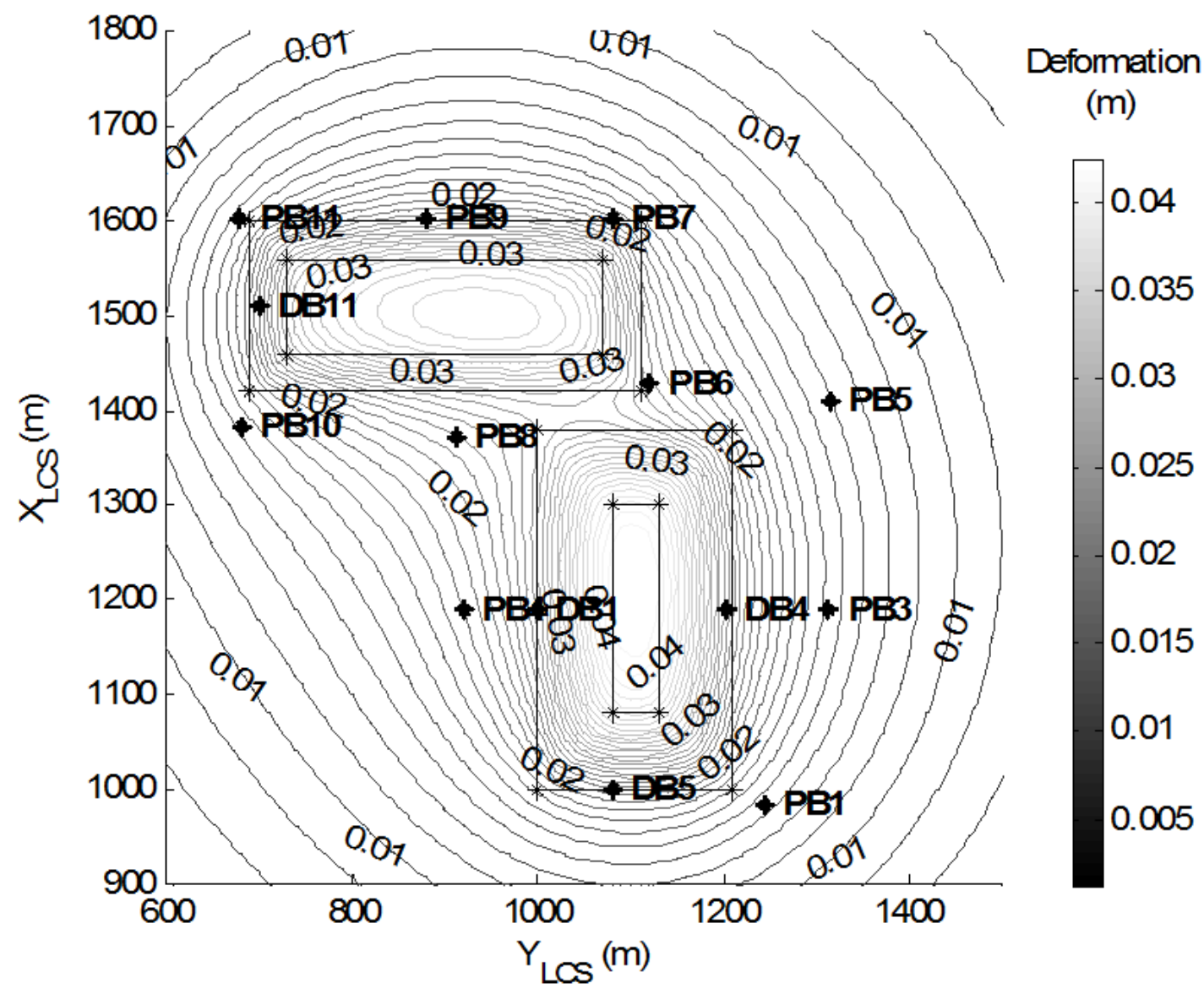

Fig. 5 Details of the situations - the points of the levelling line and deformations caused by the structure of the pits.

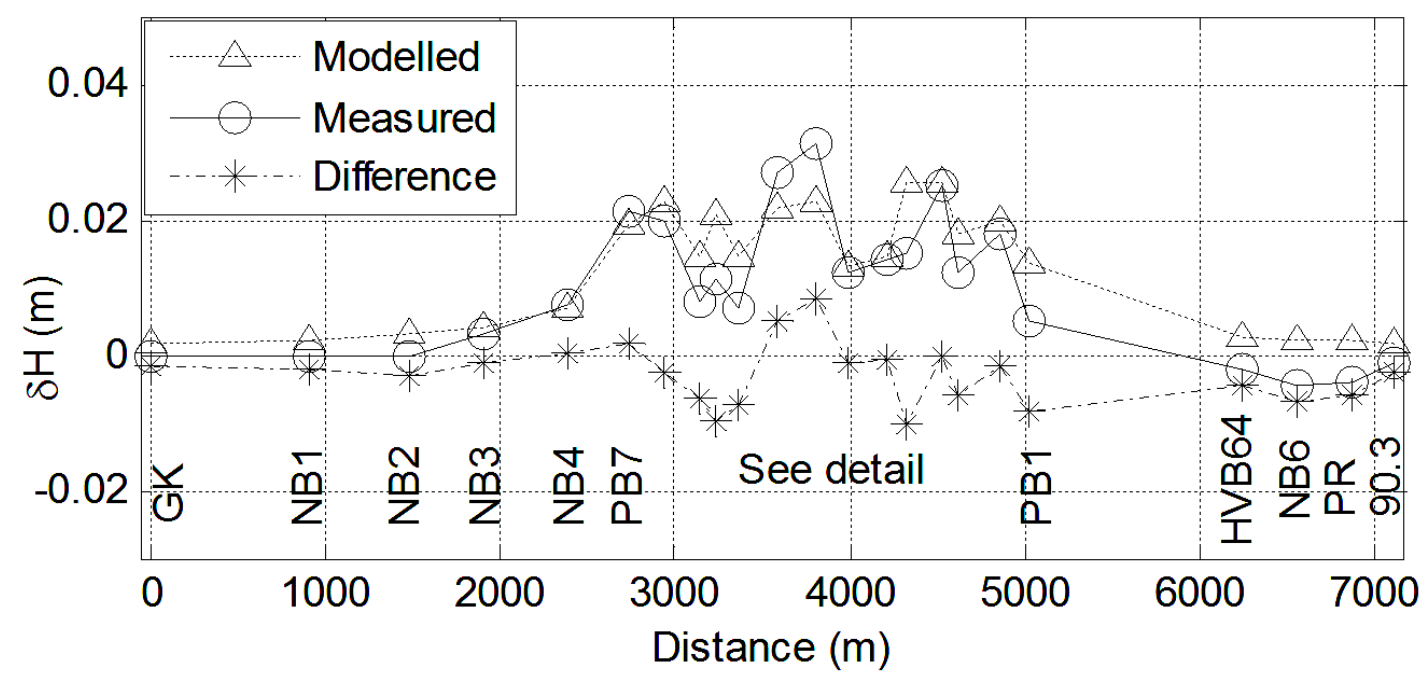

Fig. 6 Leveling line with measured height differences, modelled deformation $(E=2914$ MPa) and their differences.

\section{EXPERIMENTAL MODELLING OF THE EARTH'S SURFACE DEFORMATIONS AFTER THE UNLOADING}

The experiment of the Earth's surface deformations due to the unloading caused by the excavation work at the building pits was based on Equation 1. An effective Young's modulus of $E=2914$ MPs, Poisson number of $\mu=0.3$, and density of $1800 \mathrm{~kg} / \mathrm{m}^{3}$ were used for this purpose. The results of the modelling of the vertical deformation are presented in Figs. 4 to 7. 


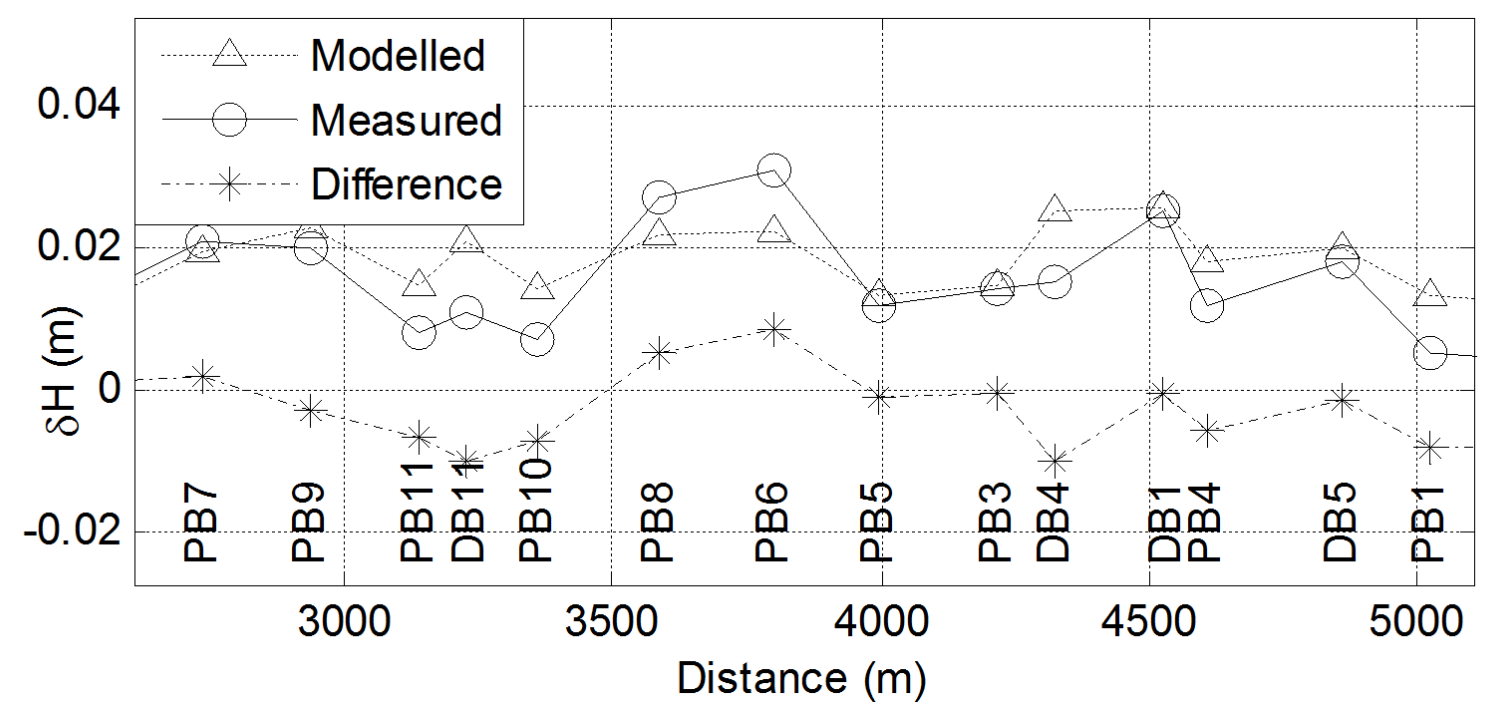

Fig. 7 Detailed situation of the levelling line with the height differences measured, modelled by E $=2914$ MPa, and their differences.

Tab. 4 The measured and modelled deformations.

\begin{tabular}{|c|c|c|c|}
\hline Point & $\begin{array}{l}\text { Measured } \\
(\mathrm{mm})\end{array}$ & $\begin{array}{l}\text { Modelled } \\
\quad(\mathrm{mm})\end{array}$ & $\begin{array}{l}\text { Difference } \\
\quad(\mathrm{mm})\end{array}$ \\
\hline GK & 0.0 & 1.5 & -1.5 \\
\hline NB1 & 0.0 & 2.1 & -2.1 \\
\hline NB2 & 0.0 & 2.9 & -2.9 \\
\hline NB3 & 3.0 & 4.0 & -1.0 \\
\hline NB4 & 7.5 & 7.1 & 0.4 \\
\hline PB7 & 21.0 & 19.2 & 1.8 \\
\hline PB9 & 20.0 & 22.8 & -2.8 \\
\hline PB11 & 8.0 & 14.6 & -6.6 \\
\hline DB11 & 11.0 & 20.9 & -9.9 \\
\hline PB10 & 7.0 & 14.3 & -7.3 \\
\hline PB8 & 27.0 & 21.9 & 5.1 \\
\hline PB6 & 31.0 & 22.5 & 8.5 \\
\hline PB5 & 12.0 & 13.1 & -1.1 \\
\hline PB3 & 14.0 & 14.7 & -0.7 \\
\hline DB4 & 15.0 & 25.3 & -10.3 \\
\hline DB1 & 25.0 & 25.4 & -0.4 \\
\hline PB4 & 12.0 & 18.0 & -6.0 \\
\hline DB5 & 18.0 & 19.6 & -1.6 \\
\hline PB1 & 5.0 & 13.4 & -8.4 \\
\hline HVB64 & -2.0 & 2.7 & -4.7 \\
\hline NB6 & -4.5 & 2.3 & -6.8 \\
\hline PR & -4.0 & 2.0 & -6.0 \\
\hline 90.3 & -1.0 & 1.8 & -2.8 \\
\hline
\end{tabular}




\section{STATISTICAL EVALUATION OF THE EXPERIMENT}

The efficiency of the proposed modelling of the vertical deformations can be statistically assessed by the use of the differences between the modelled and measured deformations. Table 4 presents the measured and modelled values. The largest discrepancy $(-10 \mathrm{~mm})$ is at point DB4. The standard deviation of the differences reached a value of $4.6 \mathrm{~mm}$.

\section{CONCLUSION}

The experiment presented allows for the formulation of the following conclusions:

1. Geodetic measurements can be used for the estimation of an effective Young's modulus or a mean Young's modulus in homogeneous sub-soil and flat areas. This modulus can serve for sufficient modelling of the vertical deformations of the Earth's surface.

2. The value of the effective Young's modulus of elasticity estimated based on the geodetic measurements was $2914 \mathrm{MPa}$ in the locality of the Gabčíkovo hydroelectric power plant.

3. The estimation of the Young's modulus with the presented method could be uncertain in an inhomogeneous environment or a broken relief. This however, requires experimental verification.

4. The accuracy achieved $(4.6 \mathrm{~mm})$ in the modelling of the vertical deformation could be increased if the control measurements were realized after the removal of all the materials. This was not observed in the case of the Gabčíkovo hydroelectric power plant as evidenced by the publication (Janek, 1998).

5. The main levelling line in the locality of the Gabčíkovo hydroelectric power plant was located in the deformation zone caused by the excavation work. The modelling showed that the height of the starting point of the levelling line at the Gabčíkovo church was changed due to the excavation work $(1.5 \mathrm{~mm})$. At least one point should be chosen outside the deformation zone.

The Gabčíkovo experiment would be difficult to repeat. This enormous structure provided a non-standard space for information about the Earth's surface deformations. This information is valuable for physicists, geologists, geophysicists, structural mechanics, geotechnical engineers and surveyors. The solution of such problems requires an integrated approach. The hidden patterns discovered can be applied not only for the construction of sophisticated structures, but also for monitoring the stability of existing structures.

\section{Acknowledgements}

This publication is the result of the implementation of the project: (National Center for Diagnostics of the Earth's Surface Deformations on the Area of Slovakia) (ITMS 26220220108), which was supported by the Research \& Development Operational Programme funded by the ERDF. 


\section{REFERENCES}

Boussinesq, J. (1885) Applications des potentials a l'Etude de l'Equilibre et Mouvements des Solides Elastiques. Gauthier Villard, Paris, $231 \mathrm{pp}$.

Grapenthin, R. - Sigmundsson, F. - Geirsson, H. - Árnadóttir, T. - Pinel, V. (2006) Icelandic thytmics: Annual modulation of land elevation and plate spreading by snow load. Geophysical Research Letters, Vol. 33, L24305.

Janek, J. (1984) Geodetic Network for the Gabčikovo Hydroelectric Power Plant. Proceedings of the workshop "Problems of the Geodetic Networks in Construction of the Power Plant", pp. 159167 (in Slovak).

Janek, J. (1998) The Influence of Mass Transportation on Level Changes of Control Network Points. Proceedings of the 1st International Conference of Engineering Surveying, pp. 257-262, ISBN 80-227-1120-9

Kollár, P. - Mojzeš, M. - Val'ko, M. (2010) Earth Surface Deformation Caused by Big Building Loading. Slovak Journal of Civil Engineering. Vol. XVIII, No. 2, ISSN 1210 - 3896
Mitáš, J. - Klajban, R. (1987) Monitoring of the Vertical Changes of Selected Points at the Gabcikovo Hydroelectric Power Plant. Proceedings of the Third Geodetic Workshop in Gabčíkovo-Nagymaros, pp. 28-33 (in Slovak).

Pinel, V. - Sigmundsson, F. - Sturkell, H. - Geirsson, H. - Einarsson, P. - Dudmundsson, M. T. - Högnadóttir, T. (2007) Discriminating volcano deformation due to magma movements and variable surface loads: application to Katla subglacial volcano, Iceland. Geophys. J. Int., 169, pp. 325-338.

Sávik, I. (2011) The method of expression of the deformation parameters of soil for the prognosis of settlement of high-rise buildings founded in deep excavation pits. Polska academia nauk odddzial w Katowicach, Komisja inzynierii budowlanej, Zeszyt 11, Katowice-Opole-Gliwice, pp. 139-144, ISSN 1505-8425

Zienkiewicz, D.C. (1972) Finite elements method. Arkady, pp. 105-106. 